\title{
BIOLOGICAL CONTROL OF Colletotrichum gloeosporioides IN PEPPER WITH ISOLATES OF Bacillus subtilis
}

\author{
Jeniffer Kelly Cortes Amaro ${ }^{1}$, Bruno Sérgio Vieira ${ }^{1}$, Luciana Alves Sousa ${ }^{1}$
}

${ }^{1}$ Universidade Federal de Uberlândia -Campus Monte Carmelo. E-mail: jeniamaro@ outlook.com; brunovieira@ufu.br; ludavis1@yahoo.com.br

\begin{abstract}
The aim of the present study is to evaluate the antagonistic potential of Bacillus subtilis isolates to Colletotrichum gloeosporioides in pepper. Twenty-one isolates were studied for their ability to inhibit pathogen in the following in vitro methodologies: paired culture technique, metabolites produced by the isolates, influence of joint inoculation and control of anthracnose in vivo (pepper fruits). The isolates BSV-05, BSV-12, BSV-17, BSV-07, BSV-16, BSV-09, BSV-20, BSV-13, and BSV-18 were promising as potential antagonists to $C$. gloeosporioides, with evident inhibition halo formation, for the paired culture technique methodology. These isolates produced thermostable metabolites against $C$. gloeosporioides evidencing antibiosis as the antagonistic mechanism involved in the suppression of the pathogen. Direct contact of the bacterial isolates with the pathogen completely inhibited the mycelial growth of $C$. gloeosporioides, except BSV-20 and BSV-09 isolates. Isolates BSV-20, BSV-18, BSV-17, BSV-07, and BSV-12 significantly inhibited anthracnose infections in post-harvest pepper fruits.
\end{abstract}

Keywords: Anthracnose, antagonism, bacterium, Capsicum

\section{CONTROLE BIOLÓGICO DE Colletotrichum gloeosporioides EM PIMENTA COM ISOLADOS DE Bacillus subtilis}

\section{RESUMO}

Objetivou-se estudar o potencial antagônico de isolados de Bacillus subtilis a Colletotrichum gloeosporioides em pimenta. Foram estudados 21 isolados quanto a capacidade de inibir o desenvolvimento do fitopatógeno nas seguintes metodologias in vitro: cultivo pareado, metabólitos produzidos pelos isolados, influência da inoculação conjunta e controle da antracnose in vivo (frutos destacados de pimenta). Os isolados BSV-11, BSV-05, BSV-12, BSV-17, BSV-07, BSV-16, BSV-09, BSV-20, BSV-13 e BSV-18 foram 
promissores como potenciais antagonistas a C. gloeosporioides, com evidente formação de halo de inibição, para a metodologia do cultivo pareado. Estes isolados produziram metabólitos termoestáveis contra $C$. gloeosporioides evidenciando ser antibiose o mecanismo antagônico envolvido na supressão do patógeno. O contato direto dos isolados bacterianos com o patógeno inibiu totalmente o crescimento micelial de $C$. gloeosporioides, exceto os isolados BSV-20 e BSV-09. Os isolados BSV-20, BSV-18, BSV-17, BSV-07 e BSV12 inibiram significativamente infecções de antracnose em frutos de pimenta em pós-colheita.

Palavras-chave: Antracnose, antagonismo, bactéria, Capsicum

\section{INTRODUCTION}

In Brazil, peppers are cultivated by family farmers practically throughout the country, providing profitability and presenting an important social aspect. Pepper culture generates employment, since it requires a large amount of labor, especially during the reproductive phase due to the need to several harvests (MOREIRA et al., 2006).

Anthracnose is one of the most important and destructive diseases of peppers in Brazil, causing direct damage to the fruits, making it unfeasible for commercialization. It is caused by a complex of species of fungi of the genus Colletotrichum such as $C$. gloeosporioides, $C$. acutatum and C. capsici. In Brazil, the species $C$. gloeosporioides is the most common one (CARVALHO \& BIANCHETTI, 2004).

The most important losses result in the symptoms of rot in fruits, being the damages in leaves and branches of minor importance. In Brazil, losses of up to $100 \%$ have been reported in highly susceptible cultivars of sweet Peppers and peppers under field conditions (LOPES \& ÁVILA, 2003). The main strategy to anthracnose control is based on the frequent application of fungicides (HADDEN \& BLACK, 1989). However, the resistance of Colletotrichum species to some active principles has been reported in vegetables (TANAKA et al., 1997; HADDAD et al., 2003). In addition, chemical control may be inefficient in some environmental conditions that are very favorable to the establishment of the disease and its dissemination as high temperatures associated with high relative humidity or frequent rains (HADDAD et al., 2003).

Thus, researches involving new technologies for the management of anthracnose in peppers such as the biological control are important (SOUSA et al., 2012). Bacteria of the genus Bacillus have been highlighted as potential biocontrol agents of plant diseases, because they have different mechanisms of action against pathogens (LANNA et al., 2010), such as Rhizoctonia solani (ASAKA \& SHODA, 1996; MELO \& FAULL, 2000), 
Fusarium spp. (SRIVASTAVA et al., 2010; CAO et al., 2011) and Sclerotinia sclerotiorum (ABDULLAH et al., 2008). In addition, these bacteria can be found in a wide variety of environments, are easy to grow, have rapid growth on a large number of substrates, and are not pathogenic to plants. They are able to inhibit phytopathogens through the production of secondary metabolites and can promote the growth of plants (HARMAN et al., 2000; ORTÍZ-CASTRO et al., 2008; LEELASUPHAKUL et al., 2008).

Considering the lack of information available in Brazil in relation to the control of C. gloeosporioides in pepper through biological control and given the importance of anthracnose to the pepper culture, the aims of this work were: to evaluate the antagonistic potential of isolates of Bacillus subtilis against $C$. gloeosporioides in vitro; and to evaluate the selected isolates for the ability to inhibit anthracnose infections in pepper fruits.

\section{MATERIAL AND METHODS}

\section{Experiment locations}

The procedures and experiments related to the isolation and selection of the antagonists were carried out at the Laboratory of Microbiology and Phytopathology of the Universidade Federal de Uberlândia, Campus Monte Carmelo, in the state of Minas Gerais, Brazil.

\section{Pathogen isolation and maintenance}

The C. gloeosporioides isolate used in this study was obtained from typical anthracnose lesions of pepper fruits collected on rural properties in the municipality of Monte Carmelo, state of Minas Gerais, Brazil and for isolation the procedure was performed according to Alfenas \& Mafia (2007). The polymerase chain reaction for identification of the genus Colletotrichum was performed with the oligonucleotides Cc1F1 (5'-ACCTAA CTGTGT CGG GC-3 ') and Cc2R1 (5'-AAA TTTGGGGGTTTTCGGG-3'), according to Cullen et al. (2002). The identification of the $C$. gloeosporioides species was performed by oligonucleotides CgInt (5'-GGC CTC CCG CCT CCG GGC GG-3 ') and ITS4 according to Mills et al. (1992). The pathogenicity of the obtained isolate was confirmed by inoculation of colonies of the fungus on detached fruits of pepper (cultivar 'Dedo-deMoça').

\section{Isolation of bacteria from soil}

The soil samples for Bacillus isolation was carried out at different sites of native forest in the city of Monte Carmelo, in the state of Minas Gerais, Brazil. Isolation of bacteria belonging to the genus Bacillus 
followed the methodology: $1 \mathrm{~g}$ of soil from each sample was suspended in $50 \mathrm{~mL}$ of the Nutrient Broth culture medium ( $5 \mathrm{~g} / \mathrm{L}$ Peptone meat, $3 \mathrm{~g} / \mathrm{L}$ meat extract, $12 \mathrm{~mL}$ of distilled water, $\mathrm{pH}$ 7.4). Then, each sample was homogenized in the vortex for one minute. A $1 \mathrm{~mL}$ aliquot was removed for the pasteurization process (12 minutes at $80^{\circ} \mathrm{C}$ in a water bath and subsequent thermal shock on crushed ice for 5 minutes), in order to select sporulating bacteria of Bacillus genus. After this period, the suspension of each sample was diluted twice, reaching a ratio of 10-2. From the last dilution, $100 \mu \mathrm{L}$ were applied in Petri dish containing Luria-Bertani culture medium (LB), followed by incubation in a BOD at $28^{\circ} \mathrm{C}$ for 48 hours.

The isolates obtained were identified molecularly being used for this work only those belonging to the species Bacillus subtilis. The polymerase chain reaction for identification of the Bacillus subtilis isolates was performed with the oligonucleotides fD1 (5'-AGAGTTTGATCCTGGCTCAG-3') and rD1 (5'AAGCTTAAGGAGGTGATCCAGCC-3'), according to Gürtler \& Stanisich (1996).

After the isolation and replication of the bacteria, the following isolates were obtained: BSV-01, BSV02, BSV-03, BSV-04, BSV-05, BSV-06, BSV-07, BSV-08, BSV-09, BSV-10, BSV-11, BSV-12, BSV-13 BSV14, BSV-15, BSV-16, BSV-17, BSV-18, BSV-19 BSV-20, BSV-21. They were kept at $4{ }^{\circ} \mathrm{C}$ in a refrigerator preserved by mineral oil conservation technique (ALFENAS \& MAFIA, 2007).

\section{Paired culture technique}

Mycelial discs ( $2 \mathrm{~cm}$ in diameter) taken from pure cultures of the pathogen were previously transferred $2 \mathrm{~cm}$ apart from the border of $9 \mathrm{~cm}$ Petri dishes containing PDA medium. Then, on the opposite side of the plates, also at a distance of $2 \mathrm{~cm}$ from the border, each antagonist also coming from pure culture was sown with an inoculation loop on the opposite side of the dish.

As a control the pathogen in question was cultivate alone in Petri dishes containing PDA medium. The plates were maintained in a BOD at $25{ }^{\circ} \mathrm{C}$ and the evaluation was done after 15 days of incubation and the diameter of the mycelial growth of the pathogen was determined with the aid of a millimeter ruler.

In order to calculate the percentage inhibition of mycelial growth the following formula was applied: $\%$ inhibition $=[($ crcontrol - crtreat $) /$ crcontrol $] \times 100$, where: crtcontrol $=$ control radial growth crtreat $=$ radial growth treatment, according to Menten et al. (1976). The experiment was conducted in a completely randomized design, with five repetitions, considering each dish as an experimental unit. The data were submitted to the Lilliefors test to test the normality and homogeneity of the variances, respectively. The analysis of variance (ANOVA, F-test at 5\% probability) and the treatments were compared using the Scott-Knott test at the 5\% probability level. 


\section{Effect of thermostable compounds produced by Bacillus subtillis isolates on $C$. gloeosporioides}

Colonies of bacteria selected in the paired culture experiment were transferred to erlenmeyer flasks containing liquid culture medium based on potato dextrose (PD), and kept at $25^{\circ} \mathrm{C}$ for seven days under stirring at $150 \mathrm{rpm}$ in the dark. After this period, bacterial suspension aliquots were transferred to Erlenmeyer flasks containing PD culture medium, resulting in concentrations of 20, 50 and $80 \%$ (v:v). PD medium added to the bacterial suspension consisted of 250, 400 and $1000 \mathrm{~g} \mathrm{~L}-1$ of potato, and 25, 40 and $100 \mathrm{~g} \mathrm{~L}-1$ of dextrose for treatments with concentrations of 20,50 and $80 \%$, respectively. Subsequently, agar was added at a concentration of $20 \mathrm{~g} \mathrm{~L}-1$, and culture media were sterilized by autoclaving for 20 minutes at $120^{\circ} \mathrm{C}$. After homogenization, $20 \mathrm{~mL}$ of the resulting suspension were poured into Petri dishes. After medium solidification, a 5-mm diameter pathogen colony disc was placed in the center of each dish. Control only contained the pathogen in PDA. After fifteen days of incubation in $\mathrm{BOD}$ at $25^{\circ} \mathrm{C}, \mathrm{C}$. gloeosporioides colony diameter was evaluated. The experiment was conducted in a randomized block design and $10 \times 3+1$ factorial (bacterial isolates $\mathrm{x}$ bacterial suspension concentrations + control), with five repetitions, where each dish was an experimental unit. Analysis of variance ( $F$ test, $\mathrm{P}=0.05$ ) of grouped data was conducted, and treatment means were compared using Tukey's test $(\mathrm{P}=$ 0.05). Comparison with control was conducted by Dunnett's test $(\mathrm{P}=0.05)$.

\section{Influence of the joint inoculation of Bacillus subtilis on the growth of $C$. gloeosporioides}

To evaluate the fungicidal or fungistatic effect on the mycelial growth of the phytopathogen in question, $100 \mu \mathrm{L}$ of culture containing each of the 10 bacterial isolates and fragments of approximately $3 \mathrm{~cm}$ of PDA culture containing mycelium of the fungus were mixed by vortexing and subsequently transferred in $9 \mathrm{~cm}$ Petri dishes containing PDA medium. Plates were incubated for 15 days at $25^{\circ} \mathrm{C}$ in a BOD chamber. The controls were composed of dishes containing only inoculum of the fungus in PDA medium. The evaluation was done after 15 days, measuring the diameter of the fungal culture grown together with the bacterial isolates, as compared to the control. For the calculation of inhibition of mycelial growth, the formula used in the paired culture experiment was used. The analysis of variance (ANOVA, F test at $5 \%$ of probability) and the treatments were performed using the Tukey test at the $5 \%$ probability level.

\section{Antagonism of Bacillus subtilis isolates to $C$. gloeosporioides in pepper fruits}

Detached pepper healthy fruits (cultivar 'Dedo-de-Moça') at the commercial maturation stage were washed and surface disinfested by immersion in $0.05 \% \mathrm{NaClO}$ for 5 minutes and then dried in a laminar flow cabinet. In each fruit, a wound was made with the aid of a syringe. For the application of the 10 bacterial antagonists that selected in the paired cultivation experiment, in each fruit a bacterial isolate was sprayed with 
bacterial isolates separately $\left(10^{8} \mathrm{CFU} \mathrm{mL}^{-1}\right)$. Suspensions were obtained by culturing each bacterial isolate separately in Petri dishes with culture medium 523 for 24 hours at $28^{\circ} \mathrm{C}$, suspended by washing the surface of the medium with tap water. The concentration of each suspension was adjusted in a spectrophotometer to obtain

$10^{8} \mathrm{CFU} \mathrm{mL} \mathrm{m}^{-1}$. The control consisted of spraying with water. In each treated fruit a C. gloeosporioides mycelium disc grown in PDA for 15 days was deposited after 2 hours of the applications of the antagonists.

The fruits were kept for 24 hours in a humid chamber. The trays containing the fruits were maintained at $25 \pm 2{ }^{\circ} \mathrm{C}$ and under light alternation ( $12 \mathrm{~h}$ light $/ 12 \mathrm{~h}$ dark). The evaluation was performed seven days after inoculation, by analyzing the anthracnose severity at each inoculated site, and the external lesion area was determined by measuring the length of the lesion in two diametrically opposite directions, using a millimeter ruler.

The experimental design was completely randomized with six replicates; each replicate being composed of three fruits. The analysis of variance (ANOVA, Test $\mathrm{F}$ at $5 \%$ probability) and the treatments were compared using the Tukey test, at a 5\% probability level. Each treatment was compared to the control by the Dunnett test at $5 \%$ probability.

\section{RESULTS AND DISCUSSION}

Most of the 23 isolates of Bacillus subtilis inhibited the mycelial growth of C. gloeosporioides (Table 1). Ten of the twenty-three bacterial isolates that were most prominent for the inhibition of mycelial growth of $C$. gloeosporioides were selected for the other experiments, namely: BSV-11, BSV05, BSV-12, BSV-17, BSV-07, BSV -16, BSV-09, BSV-20, BSV-13 and BSV-18. These isolates are promising as potential antagonists to $C$. gloeosporioides, reducing fungal mycelial growth between $48.75 \%$ and $72.01 \%$, with evident inhibition halo formation. Some studies infer that percentages of inhibition of mycelial growth of pathogens of $40 \%$ or more indicate a potential biological control agent (LANNA et al., 2010). The direct antagonism of Bacillus subtilis against pathogens involves the known mechanisms of antibiosis such as the synthesis of antimicrobial substances, competition for space and nutrients and the synthesis of volatile compounds (LEELASUPHAKUL et al., 2008). 
Table 1. Antagonistic effect of Bacillus subtilis isolates on mycelial growth (colony diameter) of Colletotrichum gloeosporioides.

\begin{tabular}{cccccc}
\hline Isolate & \multicolumn{2}{c}{ Mycelial growth $(\mathrm{cm})$} & \multicolumn{2}{c}{ Isolate } & \multicolumn{2}{c}{ Mycelial growth $(\mathrm{cm})$} \\
\hline BSV11 & 2.25 & $\mathrm{a}^{(1)}$ & BSV04 & 4.50 & $\mathrm{~b}$ \\
BSV-05 & 2.33 & $\mathrm{a}$ & BSV-19 & 4.54 & $\mathrm{~b}$ \\
BSV-12 & 3.11 & $\mathrm{a}$ & BSV-09 & 4.71 & $\mathrm{~b}$ \\
BSV-17 & 3.38 & $\mathrm{a}$ & BSV-15 & 4.83 & $\mathrm{~b}$ \\
BSV-07 & 3.44 & $\mathrm{a}$ & BSV-21 & 4.96 & $\mathrm{~b}$ \\
BSV-16 & 3.70 & $\mathrm{a}$ & BSV-10 & 5.17 & $\mathrm{~b}$ \\
BSV-09 & 3.70 & $\mathrm{a}$ & BSV-06 & 5.60 & $\mathrm{c}$ \\
BSV-20 & 3.98 & $\mathrm{~b}$ & BSV-14 & 5.62 & $\mathrm{c}$ \\
BSV-13 & 4.10 & $\mathrm{~b}$ & BSV-02 & 5.90 & $\mathrm{c}$ \\
BSV-18 & 4.12 & $\mathrm{~b}$ & BSV-01 & 6.62 & $\mathrm{c}$ \\
BSV-15 & 4.14 & $\mathrm{~b}$ & BSV-08 & 7.42 & $\mathrm{~d}$ \\
\hline BSV-03 & 4.40 & $\mathrm{~b}$ & Control & 8.04 & $\mathrm{~d}$ \\
\hline
\end{tabular}

${ }^{(1)}$ Means followed by the same letter in the column do not differ by Scott-Knott's test at the 5\% probability level.

Similar results were described by other study groups that employed similar methodology to evaluate the fungistatic activity of Bacillus spp. and B. subtilis against pathogens (KUPPER et al., 2003; ANGONESE et al., 2009; SAHARAN, 2011; SINGH et al., 2001; KONUSNY-ANDREANI et al., 2014; VAFADAR et al., 2014). Evaluating the fungistatic effect of Bacillus thuringiensis, Batista Junior et al. (2002) found inhibition of the bacteria in relation to the growth of Fusarium sp. and Colletotrichum sp. isolated from soybean and cotton crops. Satisfactory results were obtained regarding the in vitro inhibition of mycelial growth of Colletotrichum acutatum (causal agent of premature fruit drop) with Bacillus spp. using the paired culture technique (FURLANI et al. 2007).

Inhibition of $C$. acutatum growth was also observed by Kupper et al. (2003) under in vitro conditions evidenced that the mechanism of action involved in the suppression of the pathogen was antibiosis. Together these studies have shown that bacteria of the genus Bacillus have great potential to be used as biological control agents of pathogenic fungi and have advantages for commercial exploitation in agriculture. Bacillus spp. are easily grown in low-cost liquid culture media that facilitate mass production in industrial fermenters. It produces resistance endospores which increases the product shelf life of products and an integrated application with chemicals (LANNA et al, 2010).

The 10 isolates that highlighted in the paired culture technique were selected for this experiment and the subsequent ones. There was a significant interaction between the doses tested and the bacterial isolates (Table 2). At the fifteenth day of evaluation, the 10 isolates tested differed statistically from the 
control (Table 2), revealing that the metabolites produced by these isolates were thermostable and maintained their activities even after autoclaving. Only BSV-05 and BSV-09 at 20\% concentration did not differ from the control (Table 2). Metabolites produced by the five isolates (BSV-20, BSV-18, BSV17, BSV-07, e BSV-16) showed a marked antifungal effect at the fifteenth day of incubation inhibiting significantly and not differentiating between the mycelial growth of the pathogen in the three concentrations tested. In general, except for the BSV-05, BSV-09 and BSV-12 isolates, at the concentration of $20 \%$, all other treatments had a colony diameter of less than $3.63 \mathrm{~cm}$ inhibiting the mycelial growth of C. gloeosporioides more than $60 \%$ in relation to control (Table 2).

Table 2. Mycelial growth of Colletotrichum gloeosporioides in Petri dishes containing PDA culture medium plus different concentrations $(\%)$ of autoclaved PD medium containing thermostable metabolites produced by Bacillus subtilis isolates after fifteen days of incubation.

\begin{tabular}{|c|c|c|c|}
\hline \multicolumn{4}{|c|}{ Diameter of the fungal colony $(\mathrm{cm})$} \\
\hline \multirow[b]{2}{*}{ Isolate } & \multicolumn{3}{|c|}{ Autoclaved bacterial suspension concentration (\%) } \\
\hline & $20 \%$ & $50 \%$ & $80 \%$ \\
\hline BSV-05 & $7.96 \mathrm{bB}^{(1)}$ & $6.33 \mathrm{cA}^{*}$ & $5.06 \mathrm{dA}^{*}$ \\
\hline BSV-07 & $3.20 \mathrm{aA}^{*}$ & $3.66 \mathrm{abA} *$ & $2.93 \mathrm{abcA} *$ \\
\hline BSV-09 & $8.66 \mathrm{bB}$ & $7.63 \mathrm{cB}^{*}$ & $5.06 \mathrm{dA}^{*}$ \\
\hline BSV-11 & $2.93 \mathrm{aA}^{*}$ & $3.90 \mathrm{bA}^{*}$ & $3.83 \mathrm{cdA}^{*}$ \\
\hline BSV-12 & $6.96 \mathrm{bB}^{*}$ & $4.13 \mathrm{bA}^{*}$ & $3.76 \mathrm{bcdA}^{*}$ \\
\hline BSV-13 & $2.96 \mathrm{aA}^{*}$ & $2.96 \mathrm{abA}^{*}$ & $5.06 \mathrm{~dB}^{*}$ \\
\hline BSV-16 & $2.86 \mathrm{aA}^{*}$ & $2.80 \mathrm{abA}^{*}$ & $2.06 \mathrm{abA}^{*}$ \\
\hline BSV-17 & $2.76 \mathrm{aA}^{*}$ & $3.16 \mathrm{abA} *$ & $2.83 \mathrm{abcA}^{*}$ \\
\hline BSV-18 & $2.90 \mathrm{aA}^{*}$ & $1.96 \mathrm{aA}^{*}$ & $1.66 \mathrm{aA}^{*}$ \\
\hline BSV-20 & $3.63 \mathrm{aB}^{*}$ & $3.33 \mathrm{abB} *$ & $1.50 \mathrm{aA}^{*}$ \\
\hline Control & 9.2 & 9.2 & 9.2 \\
\hline $\mathrm{CV}(\%)$ & 16.46 & & \\
\hline
\end{tabular}

${ }^{(1)}$ Means by same capital letters in the line and small letters in the column do not differ from each other by the Tukey test at the $5 \%$ probability level. (*) Means followed by an asterisk differ significantly from the control, at 5\% probability, by the Dunnett test.

At the concentration of 50\%, it was observed that only two isolates, BSV-09 and BSV-05, did not stand out in relation to the others, maintaining the fungal colony diameter between $7.63 \mathrm{~cm}$ and 6.33 $\mathrm{cm}$, respectively, when compared to control in which the mycelial growth of the fungus was $9.2 \mathrm{~cm}$. The others isolates maintained the diameter of the $C$. gloeosporioides colony below $4.13 \mathrm{~cm}$, inhibiting in more than $87.5 \%$ the mycelial growth of $C$. gloeosporioides in relation to the control with a high 
antifungal action (Table 2). At the concentration of $80 \%$, all the isolates showed an antifungal effect on the mycelial growth of the pathogen especially the isolates BSV-20, BSV-18, BSV-17, BSV-16 e BSV07, That kept the colony diameter below $2.93 \mathrm{~cm}$, differing from the other isolates (Tabela 2), suggesting that the metabolites produced by these isolates have a more pronounced antifungal effect than $C$. gloeosporioides (Table 2).

The results obtained in the present work are quite significant and it can be inferred that all ten $B$. subtilis isolates tested in this methodology, with the exception of the BSV - 05 and BSV - 09 isolates, presented high antagonistic potential against the tested pathogen. These results demonstrate that inhibition of mycelial growth was due to antibiosis, suggesting the production of extracellular secondary metabolites by antifungal bacterial isolates, which may be antibiotics, chitinases, glucanases and other types of polypeptides (AMIN et al., 2012).

It is probable that mycelial growth inhibition is a result of the release of metabolites by the isolates, which may be responsible for the inhibition of fungus growth, because isolates of $B$. subtilis produce a large variety of antifungal metabolites, among which are lipopeptides from families of surfactin, iturin and fengicin. These peptides are cyclic compounds of seven or ten $\alpha$-amino acids linked to a single $\beta$-amino (iturins) or $\beta$-hydroxy (surfactins and fengicins) fatty acid (ONGENA et al. 2005). The length of this chain of fatty acids can range from $\mathrm{C} 13$ to $\mathrm{C} 16$ for surfacins, from $\mathrm{C} 14$ to $\mathrm{C} 17$ to iturins and from C14 to C18 in the case of fengicins (ONGENA et al., 2005). Although structurally similar, surfactins, iturins and fengicins differ in some biological aspects in relation to their activity. As an example, iturins and fengicins exhibit strong antifungal activity and are inhibitory to the growth of a wide range of pathogens. As for surfactins, they are not fungitoxic in themselves, but exert some synergistic antifungal effect when in the company of iturin A (LANNA FILHO et al., 2010).

Other authors have demonstrated by methodologies similar to the present work the action of metabolites produced by bacteria of the genus Bacillus against others pathogenic fungi. It was demonstrated that isolates of $B$. thuringiensis were efficient in producing metabolites that inhibited the growth of important pathogens such as Sclerotium rolfsii and Rhizoctonia solani (REMUSKA et al., 2007).

Mycelial growth of $C$. gloeosporioides was highly influenced when placed in direct contact with Bacillus subtilis isolates. This is due to a greater interaction between the bacterium and the phytopathogen in question when compared to the previous experiments. All isolates differed statistically from the control reaching up to $100 \%$ inhibition on the phytopathogen in question, except for the BSV- 
20 and BSV-09 isolates which had a lower fungicidal effect than the other bacterial isolates but higher than the control with percentages of inhibition of mycelial growth of $52.3 \%$ and $38.4 \%$, respectively (Table 3).

Table 3 - Diameter of the fungal culture of Colletotrichum gloeosporioides together with Bacillus subtilis isolates in Petri dishes containing PDA medium after 15 days of incubation.

\begin{tabular}{|c|c|c|c|}
\hline \multirow[b]{2}{*}{ Isolate } & \multicolumn{3}{|c|}{ Diameter of the fungal culture $(\mathrm{cm})$} \\
\hline & \multicolumn{3}{|c|}{..................15 days.................. } \\
\hline BSV-11 & $0 \mathrm{a}^{(1)}$ & BSV-13 & $1,45 \mathrm{~b}$ \\
\hline BSV-12 & $0 \mathrm{a}$ & BSV-17 & $2,26 \mathrm{~b}$ \\
\hline BSV-16 & $0 \mathrm{a}$ & BSV-09 & $4,25 \mathrm{c}$ \\
\hline BSV-05 & $0 \mathrm{a}$ & BSV-20 & $5,48 \mathrm{c}$ \\
\hline BSV-07 & $0 \mathrm{a}$ & & \\
\hline BSV-18 & $0 \mathrm{a}$ & & \\
\hline Control & & 8,91 & \\
\hline
\end{tabular}

(1) Means followed by the same letter do not differ by Tukey test at the 5\% probability level.

These results differ from those obtained with the paired culture technique in which very contrasting values of mycelial inhibition were observed in relation to the same isolates tested in the joint inoculation experiment. In order to evaluate and select potential antagonists we must test different methodologies (LANNA et al. 2010).

Figueiredo et al. (2009) tested the isolate CNPMS-22 (B. subtilis) against six phytopathogenic fungi (Fusarium moniliforme, Exserohilum turcicum, Acremonium striticum and Colletotrichum sublineolum), causal agents of disease in maize and sorghum crops. In this work, the isolate of B. subitilis CNPMS-22 inhibited the growth of all six phytopathogenic fungi species tested and no significant variations were observed in the results between the three experiments: inoculation of fungal culture fragments in an established culture of the CNPMS-22, inoculation of the bacterium after establishment of the fungus culture in one of the halves of dishes containing LB or PDA and inoculation together bacterium CNPMS-22 + fungus.

It can infer that to really confirm the antagonistic potential of a microorganism it is essential to perform several tests both in vitro and in vivo conditions since we can observe differences in inhibitions between pathoystems and methodologies (DEV SHARMA et al., 2013; YAN et al., 2011). 
After the selection of the best isolates that proved to be promising for the control of $C$. gloeosporioides in vitro, the in vivo study on pepper fruits was carried out in order to verify if the isolates would maintain the same inhibition pattern. The isolates BSV-20, BSV-12, BSV-18, BSV-07 and BSV-17 significantly inhibited the development of the fungus in the fruits, reducing the lesion caused by the pathogen (Table 4), showing percentages of inhibition of the pathogen of $64.2 \% ; 49.5 \%$; $48.2 \% ; 43.0 \%$ and $32.32 \%$, respectively.

Table 4 - Injured area $\left(\mathrm{cm}^{2}\right)$ in detached pepper fruits after 7 days of application of suspension of Bacillus subtilis isolates

\begin{tabular}{cccc}
\hline Isolate & \multicolumn{1}{c}{ Injured area $\left(\mathrm{cm}^{2}\right)$ by $C$. gloeosporioides in pepper fruit } \\
\hline BSV-20 & $0.83 \mathrm{a}^{(1)}$ & BSV-11 & $1.96 \mathrm{~b}^{*}$ \\
BSV-12 & $1.17 \mathrm{a}$ & BSV-05 & $1.97 \mathrm{~b}^{*}$ \\
BSV-18 & $1.20 \mathrm{a}$ & BSV-09 & $2.06 \mathrm{~b}^{*}$ \\
BSV-07 & $1.32 \mathrm{a}$ & BSV-16 & $2.22 \mathrm{~b}^{*}$ \\
BSV-17 & $1.57 \mathrm{a}$ & & \\
BSV-13 & $1.91 \mathrm{~b}^{*}$ & & \\
Control & & 2.32 \\
\hline
\end{tabular}

(1) Means followed by the same letter do not differ by Tukey test at the 5\% probability level. (*) Means followed by an asterisk do not differ significantly from the control, at 5\% probability, by the Dunnett test.

Bacteria of the genus Bacillus take advantage of the biological control of diseases by forming endospores that favor its survival, facilitating the manipulation, formulation and support relatively long periods of storage while maintaining its efficiency (WARRIOR et al. 2002) being an alternative in the reduction of postharvest rot of several crops.

It was evaluated that the use of antagonists and alternative products in the post-harvest rot of sweet peppers and verified that the bacterium C116 (Bacillus pumilus) stood out in relation to the other treatments, revealing satisfactory results, indicating that it is possible alternative in the postharvest management of this disease (SILVA et al., 2014). It was found that the use of $B$. amyloliquefaciens significantly reduced the rot caused by Botrytis and Rhizopus in raspberry without interfering in their physicochemical characteristics (ANTONIOLLI et al., 2011). It was related that B. subtilis (PPCB001) and B. amyloliquefaciens (PPCB004) isolates associated with modified atmosphere packaging reduced the incidence of Penicillium crustosum in 'Valencia' orange fruit (WARRIOR et al., 2002). 
It was reported that isolates of B. subtilis (M4) reduced the population of Botrytis cinerea in apple by more than $70 \%$ within 15 days after inoculation, in treatment 24 hours before inoculation with the pathogen (ONGENA et al., 2005). Bacillus spp. can present different mechanisms of action on pathogens, such as competition (by space and nutrients), synthesis of volatile compounds, and especially synthesis of antimicrobial substances (antibiosis) (LEELASUPHAKUL et al., 2008).

\section{CONCLUSIONS}

BSV-20, BSV-18, BSV-17, BSV-07, and BSV-12 isolates of Bacillus subtilis reduce the mycelial growth of $C$. gloeosporioides presenting a high antagonistic potential as observed in the experiments. These isolates inhibited anthracnose infections in pepper fruits detached between 32 and $64 \%$, showing promise for the control of anthracnose in pepper culture.

\section{REFERENCES}

ABDULLAH, M.T.; ALI, N.Y.; SULEMAN, P. 2008. Biological control of Sclerotinia sclerotiorum (Lib.) de Bary with Trichoderma harzianum and Bacillus amyloliquefaciens. Crop Protection, Guildford, Surrey, v.10, p.1354-1359.

ALFENAS, A.C.; MAFIA, R.G. 2007. Métodos em Fitopatologia. Viçosa, MG, UFV, 382p.

AMIN, A.; KHAN, M.A.; EHSANULlAH, M.; HAROON, U.; AZAM, S.M.F.; HAMEED, A. 2012. Production of peptide antibiotics by Bacillus sp: GU 057 indigenously isolated from saline soil. Brazilian Journal Microbiology, São Paulo, SP, v.43, p.1340-1346.

ANGONESE, M.T.; DELlA-GIUSTINA, J.; PAIM, L. H.; PANSERA, M. R.; PAGNO, R. S.; MEZZOMO, F., ZORZI, E.; PEREIRA, C.O. F.; RIBEIRO, R.T.S. 2009. Fungistatic effect of Bacillus spp. on plant pathogenic fungi. Revista Brasileira de Agroecologia, Porto Alegre, RS, n. 4, p. 97-100.

ANTONIOLLI, L. R et al. 2011. Controle alternativo de podridões pós-colheita de framboesas. Pesquisa Agropecuária Brasileira, Brasília, DF, v. 46, n. 9, p. 979-984.

ASAKA, O.; SHODA, M. 1996. Biocontrol of Rhizoctonia solani damping-off of tomato with Bacillus subtilis RB14. Applied Environmental Microbiology, Washington DC, v.62, p.4081-4085.

BATISTA JÚNIOR, C. B.; ALBINO, U. B.; MARTINES, A. M.; SARIDAKIS, D. P.; MATSUMOTO, L. S.; AVANZI, M. A.; ANDRADE, G. 2002. Efeito fungistático de Bacillus thuringiensis e de outras bactérias sobre alguns fungos fitopatogênicos. Pesquisa Agropecuária Brasileira, Brasília, DF, v. 37, n. 8, p. 1189-1194.

BONATELLI, M.L. 2012. Bactérias endofíticas e epifíticas cultivadas e não cultivadas do guaranazeiro e o controle da antracnose. 2012. 84 p. Dissertação (Mestrado em Genética e Melhoramento de Plantas) - Escola Superior de Agricultura "Luiz de Queiroz", Piracicaba, SP.

CAMPOS SILVA, J.R.; SOUZA, R.M.; ZACARONE, A.B.; SILVA, L.H.C.P.; CASTRO, A.M.S. 2008. Bactérias endofíticas no controle e inibição in vitro de Pseudomonas syringae pv. Tomato, agente da pinta bacteriana do tomateiro. Ciência e Agrotecnologia, Lavras, MG, v.32, p.1062-1072. 
CAO, Y.; ZHANG, Z.; LING, N.; YUAN, Y.; ZHENG, X.; SHEN, B.; SHEN, Q. 2011 Bacillus subtilis SQR 9 can control Fusarium wilt in cucumber by colonizing plant roots. Biology and Fertility of Soils, Firenze, Italy, v.47, p.495-506.

CARVALHO, S. I. C.; BIANCHETTI, L. B. Sistema de produção de pimentas. 2004. Available in: <http://www.cnph.embrapa.br/sistprod/pimenta/botanica.htm>. Brasília, DF. Accessed in: 10 jan. 2017.

CULLEN, D.W.; LEES, A.K.; TOTH, I.K.; DUNCAN, J.M. 2002. Detection of Colletotrichum coccodes from soil and potato tubers conventional and quantitative real-time PCR. Plant Pathology, Oxford, v. 51, n.3, p.281-292.

DEV SHARMA, S.C.; SHOVON, M. S.; JAHAN, M. G. S; ASADUZZAMAN, A.K.M.; RAHAMAN, M.A.; BISWAS, K.K.; ABE, N. R. 2013 Antibacterial and cytotoxic activity of Bacillus methylotrophicus-scs 2012 isolated from soil. Journal of Microbiology, Biotechnology and Food Sciences, Nitra, Slovakia, v. 2, p. 2293-2307.

FIGUEIREDO, J.E. F.; GOMES, E.A.; GUIMARÃES, C. T.; LANA, U.G. P.; TEIXEIRA, M. A.; LIMA, G.V. C.; BRESSAN, W. 2009. Molecular analysis of endophytic bacteria from the genus Bacillus isolated from tropical maize (Zea mays L.). Brazilian Journal of Microbiology, São Paulo, SP, v. 40, p. 522-534.

FURLANI, A. C. F. A.; CAMARGO, M.; PANIZZI, R. C, PEREIRA, C. F. 2007. Atividade de células, filtrado e autoclavado de Bacillus spp. como bioagentes de controle de Colletotrichum acutatum. Científica, Jaboticabal, SP, v. 35, n. 2, p. 196 - 200.

GÜRTLER, V.; STANISICH, V.A. 1996. New approaches to typing and identification of bacteria by using the 16S-23S rDNA spacer region. Microbiology, Russian, 142, 3-16.

HADDAD, F.; MAFFIA, L. A.; MIZUBUTI, E. S. G. Avaliação de fungicidas para o controle de Colletotrichum gloeosporioides em cebola. Fitopatologia Brasileira, Brasília, DF, v. 28, p. 435437, 2003.

HADDEN, J. F.; BLACK. 1989. Antrachnose of pepper caused by Colletotrichum spp. Tomato and pepper production in the Tropics. Taiwan: AVRDC. p. 189-199.

HARMAN, G.E. 2000. Myths and dogmas of biocontrol. Changes in perceptions derived from research on Trichoderma harzianum T-22. Plant Disease, Ames, Iowa, v.84, p.376-393.

KONUSNY-ANDREANI, D.I.; AGIADO, J.C.; ANDREANI JUNIOR, R. 2014. Efeito de bactérias rizosféricas sobre o desenvolvimento da cenoura. Revista da Universidade Vale do Rio Verde, Três Corações, MG, 12, 211-220.

KUPPER, K.C.; GIMENES-FERNANDES, N.; GOES, A. 2003. Controle biológico de Colletotrichum acutatum, agente causal da queda prematura dos frutos cítricos. Fitopatologia Brasileira, Brasília, DF, v. 28, p.251-257.

LANNA FILHO, R.; FERRO, H. M.; PINHO, R. S. C. 2010 Controle biológico mediado por Bacillus subtilis. Revista Trópica - Ciências Agrárias e Biológicas, Chapadinha, MA, v. 4, n. 2, p. 12-20.

LEELASUPHAKUL, W. et al. 2008. Growth inhibitory properties of Bacillus subtilis strains and their metabolites against the green mold pathogen (Penicillium digitatum Sacc.) of citrus fruit. Postharvest, Biology and Technology, Leuven, Belgium, v.48, p.113-121.

LEELASUPHAKUL, W.; HEMMANEE, P.; CHUENCHITT, S. 2008. Growth inhibitory properties of Bacillus subtilis strains and their metabolites against the green mold pathogen (Penicillium digitatum Sacc.) of citrus fruit. Postharvest Biology and Technology, Leuven, Belgium, v. 48, n. 1, p. 113121.

LOPES, C. A.; ÁVILA, A. C. 2003. Doenças do pimentão: diagnose e controle. Brasília, DF: Embrapa Hortaliças. 96 p. 
MELO, I. S.; FAULL, J. L. 2000. Parasitism of Rhizoctonia solani by strains of Trichoderma spp. Scientia Agrícola, Piracicaba, SP, v.57, n.1, p.55-59.

MENEZES, M.; ASSIS, S.M.P. 2004. Guia prático para fungos fitopatogênicos. 2. ed. Recife - PE: Imprensa Universitária, UFRPE.

MENTEN, J.O.M.; MINUSSI, C.C.; CASTRO, C.; KIMATI, H. 1976. Efeito de alguns fungicidas no crescimento micelial deMacrophomina phaseolina (Tass.) Goid. "in vitro". Fitopatologia Brasileira, Brasília, DF, v.1, n.2, p.57-66.

MILLS, P.R.; SREENIVASAPRASAD, S.; BROWN, A.E. 1992. Detection and differentiation of Colletotrichum gloeosporioides isolates using PCR. FEMS Microbiology Letters, Amsterdam, v. 98, n.1/3, p.137-144.

MOREIRA, G.R.; CALIMAN, F.R.B.; SILVA, D.J.H.; RIBEIRO, C.S.C 2006. Espécies e variedades de pimenta. Informe Agropecuário, Belo Horizonte, MG, v.27, n.235, p.16-29.

ONGENA, M. et al. 2005. Bacillus subtilis M4 decreases plant susceptibility towards fungal pathogens by increasing host resistance associated with differential gene expression. Applied Microbiology and Biotechnology, Wolverhampton, v. 67, n. 5, p. 692-698.

ORTÍZ-CASTRO, R.; VALENCIA-CANTERO, E.; LÓPEZ-BUCIO, J. 2008. Plant growth promotion by Bacillus megaterium involves cytokinin signaling. Plant Signal Behavior, Bonn, Germany v.3, p.263-265.

REMUSKA, A.C.; PRIA, M.; DALLA. 2007. Efeito de Bacillus thuringiensis e Trichoderma sp. no crescimento de fungos fitopatogênicos. Ciência Agrícola. Maceió, AL, v. 13, p. 31-36.

SAHARAN, B. S. 2011. Plant Growth Promoting Rhizobacteria: A Critical Review. Life Sciences and Medicine Research. Kurukshetra, Haryana. 30p.

SILVA, M. M.; CARVALHO, F. C. Q.; SILVA, J. R.; LINS, S. R. O.; OLIVEIRA, S. M. A. 2014. Uso de antagonistas e produtos alternativos no manejo pós-colheita de podridão mole em pimentão. Revista Ciência Agronômica, Fortaleza, CE, v. 45, n. 4, p. 718-725.

SINGH, J.S.; PANDEY, V.C.; SINGH, D.P. 2001. Efficient soil microorganisms: a new dimension for sustainable agriculture an environmental development. Agriculture. Ecosystems Environment. Zurich, Switzerland, 140, 3-4, 339-353.

SOUSA, R.M.S; SERRA, I.M.R.S; MELO, T.A. 2012. Efeito de óleos essenciais como alternativa no controle de Colletotrichum gloeosporioides, em pimenta. Summa Phytopathologica, Botucatu, SP, v.38, n.1, p.42-47.

SRIVASTAVA, R.; KHALID, A.; SINGH, U.S.; SHARMA, A.K. 2010. Evaluation of arbuscular mycorrhizal fungus, fluorescent Pseudomonas and Trichoderma harzianum formulation against Fusarium oxysporum f. sp. lycopersici for the management of tomato wilt. Biological Control, Texas, USA, v.53, p.24-31.

WARRIOR, P.; KONDURU, K.; VASUDEVAN, P. 2002. Formulation of biological control agents for pest and disease management. In: GNANAMANICKAM, S. S. (Ed.). Biological control of crop diseases. New York: Marcel Dekker. p. 421-441.

WORLD HEALTH ORGANIZATION. 1985. Informal consultation on the development of Bacillus sphaericus as microbial larvicide. Geneva: UNDP/World Bank/WHO Special programmer of research and training in tropical diseases. 24p.

TANAKA A. S.; PASSOS, F. A.; BETTI, J. A. 1997. Resistência de Colletotrichum fragariae e C. acutatum ao benomyl na cultura do morango no Estado de São Paulo. Scientia Agricola, Piracicaba, SP, v. 54, p.139-146. 
VAFADAR, F.; AMOOAGHAIE, R.; OTROSHA, M. 2014. Effects of plant-growth-promoting rhizobacteria and arbuscular mycorrhizal fungus on plant growth, stevioside, NPK, and chlorophyll content of Stevia rebaudiana. Journal of Plant Interactions, United Kingdom, 9, 128-136.

YAN, X.; HE, L.; SONG, G.; WANG, R. 2011. Antagonistic bioactivity of endophytic strains isolated from Salvia miltiorrhiza. African Journal of Biotechnology, Bowie, USA. v. 10, p. 15117-15122.

Received in: May 11, 2017 Accepted in: August 14, 2017 